Volume 8

$5-1-2014$

\title{
Interim Editors' Introduction
}

Kjell Anderson

Amy Fagin

Melanie O'Brien

Rafiki Ubaldo

Follow this and additional works at: https://digitalcommons.usf.edu/gsp

\section{Recommended Citation}

Anderson, Kjell; Fagin, Amy; O'Brien, Melanie; and Ubaldo, Rafiki (2014) "Interim Editors' Introduction," Genocide Studies and Prevention: An International Journal: Vol. 8: Iss. 2: 1.

DOI:

http://dx.doi.org/10.5038/1911-9933.8.2.1

Available at: https://digitalcommons.usf.edu/gsp/vol8/iss2/3

This Editorial is brought to you for free and open access by the Open Access Journals at Digital Commons @ University of South Florida. It has been accepted for inclusion in Genocide Studies and Prevention: An International Journal by an authorized editor of Digital Commons @ University of South Florida. For more information, please contact digitalcommons@usf.edu. 


\section{Interim Editors' Introduction}

Issue 8.2 of Genocide Studies and Prevention: An International Journal will be the second and final issue edited and published by the Interim Editorial Board, consisting of Kjell Anderson, Amy Fagin, Melanie O'Brien, and Rafiki Ubaldo. We have been assisted by the guest editors of this issue, Kosal Path and Elena Lesley-Rozen. The goal of this issue was to reflect some of the different justice issues facing the Cambodians in the wake of the Cambodian genocide perpetrated by the Khmer Rouge.

We have been very appreciative of the University of South Florida for hosting this new, online and open access version of GSP, and look forward to a long future working together.

The next issue of GSP will be directed by the newly appointed Editorial Board. The members of this board are listed below. The IAGS plans to continue to build on the strong tradition of GSP by connecting to new audiences and broadening the disciplinary scope of the journal.

The Interim Editorial Board welcomes the new Editorial Board, and wishes them the best of luck at the helm of GSP.

The call for papers for Issue 8.3, on Humanitarian Technologies and Genocide Prevention, is available on the GSP website at http://scholarcommons.usf.edu/gsp/Call for Papers.pdf, and the call for peer reviewers for the same issue is at http://scholarcommons.usf.edu/gsp/Call for Peer Reviewers.pdf.

The new Editorial Board has also opened up a call for co-editors, specifically for the rubrics of book review, film review and Internet resources. This call is available at http://scholarcommons.usf.edu/gsp/call for editors.pdf.

Scholars in the field and other readers of GSP are encouraged to open an account at http://scholarcommons. usf.edu/gsp/ for news and information on new calls for papers, peer reviewing, and other GSP related activities.

Kjell Anderson, Amy Fagin, Melanie O’Brien, and Rafiki Ubaldo Interim Editorial Board

\section{New GSP Editorial Board}

\section{Editors-in-Chief}

Christian Gudehus, PhD, Ruhr-Universität Bochum

Gabriel Gatti, PhD, Centro de Estudios sobre la Identidad Colectiva, University of the Basque Country James Waller, PhD, Cohen Professor of Holocaust and Genocide Studies, Keene State College

\section{Associate Editors}

Melanie O'Brien, PhD, ARC Centre of Excellence in Policing and Security, Griffith University

Douglas Irvin-Erickson, PhD, Rutgers University

\section{Production Editors}

Julie Fielding, University of South Florida

Rebel Cummings-Sauls, University of South Florida

Rafiki Ubaldo, Media and Communication, IAGS 